\title{
A single nucleotide polymorphism, rs129679860, in the IL28B locus is associated with the viral kinetics and a sustained virological response in a chronic, monoinfected hepatitis $\mathrm{C}$ virus genotype-1 Brazilian population treated with pegylated interferon-ribavirin
}

\author{
Juliene Antonio Ramos ${ }^{1,3,4}$, Ana Lúcia de Araújo Ramos ${ }^{2}$, Luisa Hoffmann ${ }^{1,4}$, \\ Renata de Mello Perez ${ }^{2}$, Henrique Sérgio Moraes Coelho ${ }^{2}$, Turán Péter Ürményi ${ }^{1,4}$, \\ Rosane Silva ${ }^{1,4}$, Edson Rondinelli ${ }^{1,2,4} /{ }^{+}$, Cristiane Alves Villela-Nogueira ${ }^{2}$ \\ 'Instituto de Biofísica Carlos Chagas Filho ${ }^{2}$ Departamento de Medicina Interna, Faculdade de Medicina, \\ Hospital Universitário Clementino Fraga Filho, Universidade Federal do Rio de Janeiro, Rio de Janeiro, RJ, Brasil \\ ${ }^{3}$ Departamento de Biotecnologia, Instituto de Educação, Ciência e Tecnologia do Rio de Janeiro, Rio de Janeiro, RJ, Brasil \\ ${ }^{4}$ Instituto Nacional para Pesquisa Translacional em Saúde e Ambiente na Região Amazônica, Conselho Nacional de Desenvolvimento \\ Científico e Tecnológico, Ministério da Ciência e Tecnologia, Brasília, DF, Brasil
}

Single nucleotide polymorphisms (SNPS) in the interleukin (IL)28B locus have been associated with a sustained virological response (SVR) in interferon-ribavirin (IFN-RBV)-treated chronic hepatitis C virus (HCV)-infected patients in European and African populations. In this study, the genotype frequency of two IL28B SNPs (rs129679860 and rs8099917) in a cohort of chronic HCV-monoinfected patients in Brazil was evaluated and the SNP sufficient to predict the treatment response outcome was determined. A total of 66 naïve genotype-1 chronic HCV-infected patients were genotyped and the associated viral kinetics and SVR were assessed. The overall SVR was $38 \%$. Both the viral kinetics and SVR were associated with rs 129679860 genotypes (CC $=62 \%$ vs. CT $=33 \%$ vs. TT $=18 \%, p=0.016)$. However, rs 8099917 genotypes were only associated with SVR (TT $=53 \%$ vs. $T G=33 \%$ vs. $G G=18 \%$; $p=0.032)$. In this population, the analysis of a single SNP, rs12979860, successfully predicts SVR in the IFN-RBV treatment of HCV.

Key words: IL28B - rs12979860 - rs8099917 - hepatitis C - treatment

Chronic hepatitis $\mathrm{C}$ virus (HCV) infection is a common cause for liver transplantation in western countries and can lead to progressive liver disease, resulting in cirrhosis and other complications including hepatocellular carcinoma (El-Serag \& Mason 1999, El-Serag 2002). Although protease inhibitors have been recently approved for HCV treatment in developing countries, the current standard treatment for HCV continues to utilise subcutaneous alpha pegylated interferon (PEG-IFN) in combination with oral ribavirin (RBV) administration for 24 or 48 weeks depending on the HCV genotype. This treatment is costly and associated with significant adverse effects, thereby resulting in reduced compliance. Furthermore, approximately half of the treated subjects achieve a sustained virological response (SVR) (Fried et al. 2002, Ferenci et al. 2005, Moraes Coelho \& Villela-Nogueira 2010). However, SVR is clearly associated with a reduced risk of long-term complications, such as cirrhosis and hepatocellular carcinoma (Poynard et al. 2000). Many predictive factors associated with the HCV treatment response have been identified (McHutchison

Financial support: CNPq, FAPERJ, INPeTAm/MST

+ Corresponding author: edrondin@biof.ufrj.br

Received 24 February 2012

Accepted 18 July 2012 et al. 2001, Ferrenci 2004, Ferenci et al. 2005, Moraes Coelho \& Villela-Nogueira 2010).

Recently, a host-specific genetic-based HCV response to treatment was described. Genome-wide association studies (GWAS) identified a single nucleotide polymorphism (SNP) located on chromosome 19 within an 80-KB region containing the genes encoding the lambda IFNs. Ge et al. (2009) observed that persons who were homozygous for the major C allele at the rs12979860 SNP in proximity to interleukin (IL)28B were two-fold more likely to respond to treatment than those who were homozygous for the alternative nucleoside (T). The results of two other GWAS demonstrated that the rs8099917 SNP is associated with a SVR to HCV treatment. This T/G SNP is located near the gene $I L 28 B$, which encodes IFN lambda 3 (Suppiah et al. 2009, Tanaka et al. 2009). Rauch et al. (2010) also reported that the frequency of the minor $\mathrm{G}$ allele was over-represented among individuals with chronic hepatitis $\mathrm{C}$ with no response to PEG-IFN and RBV compared with those who achieved a SVR (Balogopal et al. 2010).

Genetic association studies require replication for use in different worldwide populations. Brazil is a large country with a population of mixed ancestry containing three million chronic HCV-infected persons. Similar to other countries, the most prevalent HCV genotype in Brazil is genotype 1 and the number of non-responders to PEG-IFN and RBV increases daily. Recently, the genotype frequencies of the IL28B SNPs rs12979860 and rs8099917 in human immunodeficiency virus (HIV)coinfected and $\mathrm{HCV}$-monoinfected Brazilian populations 
have been reported (de Araujo et al. 2011, Cavalcante et al. 2012, Lunge et al. 2012). However, it is not known whether the genotyping of both polymorphisms would be relevant to therapeutic determinations. Thus, the objective of this study was to describe the frequency of the IL28B C/T SNP for rs12979860 and that of the T/G SNP for rs8099917 in a cohort of Brazilian patients with genotype 1 chronic HCV infections treated with PEG-IFN and RBV. In addition, we evaluated the association of both IL28B SNPs with SVR in this population and investigated whether the determination of both IL28B SNPs would contribute to the prediction of SVR in these patients.

\section{PATIENTS, MATERIALS AND METHODS}

Naïve chronic HCV genotype-1-infected outpatients attending the Liver Clinic/University Hospital of the Federal University of Rio de Janeiro (HU-UFRJ), Brazil, treated with PEG-IFN and RBV from May 2005-Dec 2007 were included in this study. Data from the study patients were subjected to a per-protocol analysis. Subjects that did not received the full course of the planned treatment, those who received less than $80 \%$ of the prescribed drug dose or those for whom treatment response information was not available were excluded from the analysis. Patients who were co-infected with either HBV or HIV or who had undergone liver transplantation were excluded from the study. Moreover, patients who had end-stage kidney disease, hepatocellular carcinoma or decompensated liver cirrhosis, as defined by a ChildPugh score greater than 6, were also excluded from this study. Informed consent was obtained from all patients and approval for this study was obtained from the Ethical in Research Committee at the HU-UFRJ.

Hepatitis $C$ treatment - Patients were treated with $1.5 \mathrm{mcg} / \mathrm{kg}$ of PEG-IFN $\alpha-2 b$ once per week and administered RBV daily according to the inclusion and exclusion criteria as previously described (Ghany et al. 2009). RBV doses were $1000 \mathrm{mg} /$ day for patients up to $75 \mathrm{~kg}$ and $1.250 \mathrm{mg} / \mathrm{day}$ for those over $75 \mathrm{~kg}$. The viral load for all patients was determined prior to treatment using real-time reverse transcription-polymerase chain reaction (RT-PCR). The on-treatment viral kinetics were also evaluated at weeks 4 and 12. The rapid virological response was defined as an undetectable HCV-RNA at the fourth week of treatment using real-time PCR (lower limit of detection $=25 \mathrm{UI} / \mathrm{L}$ ). The early virological response (EVR) was defined as an at least two-log drop in the viral load at week 12 compared to the pre-treatment viral load level and the complete EVR (cEVR) was defined as undetectable HCV-RNA at the 12th week of treatment using real-time RT-PCR. When an EVR was achieved, treatment was maintained for 48 weeks. Otherwise, treatment was discontinued at the 12th week and the patients were considered nonresponders.

IL28B genotyping - All patients were genotyped for the rs12979860 and rs8099917 polymorphisms. Genomic DNA was extracted from peripheral blood using a standard method for DNA precipitation by the addition of inorganic salts. The polymorphisms were genotyped using PCR with specific primers as follows: IL28B rs8099917, 5'-CCACTTCTGGAACAAATCGTC-3' and
5'GATACGCTATAATTAAAGATGTGGGA-3' in 35 cycles at $94^{\circ} \mathrm{C}$ for $30 \mathrm{~s}, 54^{\circ} \mathrm{C}$ for $45 \mathrm{~s}$ and $72^{\circ} \mathrm{C}$ for $1 \mathrm{~min}$ and IL28B rs12979860, 5'-TCGCCAGGGCCCCTAAC CTCTGC-3' and 5'-CGCCCAGCAGGCGCCTCTCCTA-3' in 35 cycles at $94^{\circ} \mathrm{C}$ for $30 \mathrm{~s}, 58^{\circ} \mathrm{C}$ for $45 \mathrm{~s}$ and $72^{\circ} \mathrm{C}$ for $1 \mathrm{~min}$. The amplified products were sequenced using the DYEnamic ${ }^{\mathrm{TM}}$ ET Dye Terminator Cycle Sequencing Kit for MegaBACE (Amersham Biosciences, Sunnyvale, CA, USA).

Statistical analyses - The data were analysed using SPSS 17.0 (SPSS for Windows, Chicago, IL). The categorical variables are presented as numbers and percentages and the continuous variables with a normal distribution are presented as the means and standard deviations. Chisquare and Fisher's exact tests were used where appropriate and $\mathrm{p}<0.05$ was considered statistically significant.

\section{RESULTS}

A total of 66 genotype- 1 chronic hepatitis $\mathrm{C}$ patients were included in this study and the IL28B rs12979860 and rs8099917 SNP genotypes were determined. The baseline and on-treatment characteristics of the included patients are shown in Table I.

Analysis of the rs12979860 polymorphism and HCV treatment - The most prevalent rs12979860 genotype was CT (44\%), followed by CC (32\%) and TT (24\%). No association was observed among the pre-treatment predictive factors of response and the genotypes of both polymorphisms (Table II). However, an association was observed between cEVR and the CC genotype (Table II). In addition, a significant association was also observed between SVR and the CC genotype for rs12979860 (CC $=62 \%$ vs. $\mathrm{CT}=33 \%$ vs. $\mathrm{TT}=18 \% ; \mathrm{p}=0.016$ ).

Analysis of the rs 8099917 polymorphism and $\mathrm{HCV}$ treatment - The most frequent rs8099917 genotype was TT (48\%), followed by GG (33\%) and TG (19\%). No as-

\section{TABLE I}

Baseline and on-treatment characteristics of the genotype-1 chronic hepatitis $\mathrm{C}$ virus (HCV) infected patients $(\mathrm{n}=66)$

\section{Variable}

\begin{tabular}{lc}
\hline Age (years) & $53 \pm 10$ \\
Male gender [n (\%)] & $38(58)$ \\
BMI (Kg/cm²) & $26 \pm 4$ \\
Abnormal ALT [n (\%)] & $46(70)$ \\
Abnormal GGT [n (\%)] & $33(50)$ \\
Cirrhosis [n (\%)] & $18(27)$ \\
RVR [n (\%)] & $4(6)$ \\
EVR [n (\%)] & $38(58)$ \\
SVR [n (\%)] & $25(38)$
\end{tabular}

ALT: alanine aminotransferase; BMI: body mass index; EVR: early virological response; GGT:gamma-glutamyl transpeptidase; RVR: rapid virological response; SVR: sustained virological response. 
sociation was observed between the pre-treatment or on-treatment variables and the rs8099917 genotypes, as shown in Table II. However, although no association was observed between the rs8099917 genotypes and the viral load and other viral kinetics variables, there was a significant association between the TT genotype and SVR $(\mathrm{TT}=53 \%$ vs. $\mathrm{TG}=33 \%$ vs. $\mathrm{GG}=18 \%$; $\mathrm{p}=0.032$ ).

Analysis of the combined rs 12979860 and rs 8099917 genotypes and SVR - The merged frequencies of the combined rs12979860 and rs8099917 genotypes are presented in Table III. The highest frequency of SVR (79\%) was observed among patients with the rs12979860 CC genotype and the rs8099917 TT genotype. A lower frequency of SVR was observed for the rs $12979860 \mathrm{CC}$ and TG (66\%) and the rs8099917 CT and TT (40\%) genotypes, which were the most frequently observed genotypes in the population. As expected, the lowest frequency of SVR (14\%) was observed when the TT and GG genotypes were present. No improved SVR prediction was observed when the genotypes of the two polymorphisms (rs12979860 with rs8099917) were combined.

\section{DISCUSSION}

The objective of this study was to determine the frequency of two IL28B locus SNPs and their association with SVR in Brazilian patients with chronic hepatitis C genotype-1 infections. This study also sought to evaluate the predictive value of these SNPs for SVR in this population, showing that a single IL28B locus SNP (rs12979860) is sufficient to predict the HCV treatment outcome.

The rs12979860 CT genotype, followed by the CC genotype, was the most prevalent in this cohort of Brazilian patients. Although these results are consistent with previous reports (Marabita et al. 2011, Cavalcante et al. 2012, Ferreira et al. 2012, Lunge et al. 2012), they differ from others (Ge et al. 2009, Thompson et al. 2010). This difference in frequency likely reflects the genetic background of the three ancestral populations (European, African and Brazilian native Amerindian) that characterise the Brazilian population (IBGE 2000, Silva \& MouraNeto 2004). The genotype frequency of the rs8099917 polymorphism was also examined in our population. The observed preponderance of the TT genotype is consistent with previous studies of Japanese, Swiss, Australian (Suppiah et al. 2009, Tanaka et al. 2009) and Brazilian (Marabita et al. 2011, Cavalcante et al. 2012, Ferreira et al. 2012) populations. According to the Human Haplotype Map project, only $15-19 \%$ of Caucasians carry the rs8099917 minor allele. Remarkably, the GG genotype was identified in $33 \%$ of Brazilian patients in the present study, which was higher than previously described in other countries. This result is consistent with the fact that allele frequencies differ considerably (2-31\%) in different ethnic groups (Lindh et al. 2010).

TABLE III

Combined genotype frequencies of the interleukin (IL)28B single nucleotide polymorphisms rs1297860 and rs8099917 $(\mathrm{n}=66)$

\begin{tabular}{lcccc}
\hline & \multicolumn{4}{c}{ rs8099917 } \\
\cline { 2 - 5 } $\begin{array}{l}\text { Rs12979860 } \\
\text { genotypes }\end{array}$ & $\begin{array}{c}\mathrm{TT} \\
\mathrm{n}(\%)\end{array}$ & $\begin{array}{c}\mathrm{TG} \\
\mathrm{n}(\%)\end{array}$ & $\begin{array}{c}\mathrm{GG} \\
\mathrm{n}(\%)\end{array}$ & $\begin{array}{c}\text { Total } \\
\mathrm{n}(\%)\end{array}$ \\
\hline $\mathrm{CC}$ & $14(21)$ & $3(5)$ & $4(6)$ & $21(32)$ \\
$\mathrm{CT}$ & $10(15)$ & $8(12)$ & $11(17)$ & $29(44)$ \\
TT & $8(12)$ & $1(2)$ & $7(11)$ & $16(24)$ \\
\hline Total & $32(48)$ & $12(19)$ & $22(33)$ & $66(100)$ \\
\hline
\end{tabular}

TABLE II

Analysis of interleukin (IL)28B rs12979860 and rs8099917 genotypes and pretreatment, on treatment characteristics and sustained virological response (SVR) $(\mathrm{n}=66)$

\begin{tabular}{|c|c|c|c|c|c|c|c|c|}
\hline \multirow{2}{*}{$\begin{array}{l}\text { IL28B } \\
\text { Variable }\end{array}$} & \multicolumn{4}{|c|}{ rs12979860 } & \multicolumn{4}{|c|}{ rs8099917 } \\
\hline & $\mathrm{CC}$ & $\mathrm{CT}$ & $\mathrm{TT}$ & $\mathrm{p}$ & $\mathrm{TT}$ & TG & GG & $\mathrm{p}$ \\
\hline Age (years $\pm \mathrm{SD})$ & $51 \pm 2$ & $56 \pm 2$ & $53 \pm 3$ & 0.30 & $51 \pm 2$ & $56 \pm 2$ & $53 \pm 3$ & 0.30 \\
\hline Male gender (\%) & 50 & 67 & 64 & 0.47 & 50 & 67 & 64 & 0.47 \\
\hline BMI (Kg/cm²) & $26 \pm 1$ & $27 \pm 1$ & $24 \pm 1$ & 0.13 & $26 \pm 1$ & $27 \pm 1$ & $25 \pm 1$ & 0.13 \\
\hline High GGT (\%) & 33 & 57 & 68 & 0.14 & 44 & 58 & 57 & 0.47 \\
\hline High ALT (\%) & 75 & 67 & 81 & 0.56 & 72 & 67 & 79 & 0.54 \\
\hline Cirrhosis (\%) & 14 & 38 & 25 & 0.17 & 25 & 42 & 23 & 0.73 \\
\hline RVR (\%) & 5 & 7 & 0 & 0.54 & 6 & 9 & 0 & 0.45 \\
\hline EVR (\%) & 95 & 54 & 47 & 0.003 & 66 & 78 & 60 & 0.44 \\
\hline cEVR (\%) & 74 & 38 & 13 & 0.001 & 48 & 33 & 40 & 0.65 \\
\hline SVR (\%) & 62 & 31 & 19 & 0.016 & 53 & 33 & 18 & 0.032 \\
\hline
\end{tabular}

ALT: alanine aminotransferase; BMI: body mass index; cEVR: complete early virological response; GGT: gamma-glutamyl transpeptidase; RVR: rapid virological response; SD: standard deviation. 
No association was observed between both the rs12979860 and rs8099917 polymorphisms and the baseline characteristics of the population included in this study. These results are consistent with previous reports in which no association between the studied polymorphisms and fibrosis was observed (Marabita et al. 2011) and differs from the results of Bochud et al. (2012), who observed an association between the inflammatory response and fibrosis. Other studies have described an association between gamma-glutamyl transpeptidase and the major rs8099917 genotype (Abe et al. 2010). Although an association between SVR and gamma-GT levels has been previously described (Villela-Nogueira et al. 2005), in the present study, an association between this enzyme and the IL28B polymorphisms was not observed. In addition, we demonstrated that the rs1297860 CC genotype is associated with cEVR. A clear association between SVR and the major C allele for rs12979860 and the major $\mathrm{T}$ allele for rs8099917 was observed. These results are consistent with previous studies (Ge et al. 2009, Suppiah et al. 2009, Balagopal et al. 2010). The presence of the C allele appears to influence the SVR; thus, it is possible that the higher prevalence of the CT genotype observed in this Brazilian cohort chronically infected with $\mathrm{HCV}$ might contribute to the observed overall lower frequency of SVR (38\%) compared with the higher rates $(40-50 \%)$ observed in studies of American and European populations (Manns et al. 2001, Fried et al. 2002, McHutchison et al. 2009). In a Brazilian population chronically infected with HCV genotype-1, the rs8099917 polymorphism appears to be a good predictor of SVR, although multicentre studies, including different Brazilian regions, should be conducted. The genotype frequencies of both the rs12979860 and rs8099917 polymorphisms have been previously associated with SVR (Fukuhara et al. 2010, Shebl et al. 2010, Tillmann et al. 2010). Finally, although previous reports have shown that the combined polymorphisms may increase the predictive value for SVR (Fischer et al. 2012), no association with SVR was observed in our population.

In conclusion, the genotyping of IL28B locus polymorphisms as predictive factors of the response to PEGIFN and RBV treatments was demonstrated in a Brazilian population. As protease inhibitors gain in popularity as HCV therapy, the implementation of IL28B genotyping in clinical practice in this population may help to delineate health policies regarding the identification of patients who might be treated without triple therapy. In this setting, genotyping of the rs 12979860 polymorphism contributes to predicting patient treatment outcome.

\section{REFERENCES}

Abe H, Ochi H, Maekawa T, Hayes CN, Tsuge M, Miki D, Mitsui F, Hiraga N, Imamura M, Takahashi S, Ohishi W, Arihiro K, Kubo M, Nakamura Y, Chayama K 2010. Common variation of IL28 affects gamma-GTP levels and inflammation of the liver in chronically infected hepatitis C virus patients. J Hepatol 53: 439-443.

Balagopal A, Thomas DL, Thio CL 2010. IL28B and the control of hepatitis C virus infection. Gastroenterology 139: 1865-1876.

Bochud PY, Bibert S, Kutalik Z, Patin E, Guergnon I, Nalpas B, Goossens N, Kuske L, Müllhaupt B, Gergach T, Heim MH, Moradpour
D, Gerny A, Malinverni R, Regenass S, Dollenmaier G, Hersch H, Martinetti G, Gorgiewski M, Bourlièrre M, Poynard T, Theodorou J, Abel L, Pol S, Dufour JF, Negro F 2012. IL28B alleles associated with poor hepatitis $\mathrm{C}$ virus (HCV) clearance protect against inflammation and fibrosis in patients infected with non-1 HCV genotypes. Hepatology 55: 384-394.

Cavalcante LN, Abe-Sandes K, Angelo ALD, Machado TMB, Lemaire DC, Mendes CMC, Pinho JR, Malta F, Lyra LGC, Lyra AC 2012. IL28B polymorphisms are marked of the therapy response and are influenced by genetic ancestry in chronic hepatitis $\mathrm{C}$ patients from an admixed population. Liver Int 32: 476-486.

de Araujo ES, Dahari H, Cotler SJ, Layden TJ, Neumann AU, Melo CE, Barone AA 2011. Pharmacodynamics of PEG-IFN-[alpha]-2 $\alpha$ and $\mathrm{HCV}$ response as a function of IL28B polymorphism in $\mathrm{HIV} / \mathrm{HCV}$ coinfected patients. J Acquir Immune Defic Syndr 56: 95-99.

El-Serag HB 2002. Hepatocellular carcinoma and hepatitis C in the United States. Hepatology 36 (Suppl.): S74-S83.

El-Serag HB, Mason AC 1999. Rising incidence of hepatocellular carcinoma in the United States. N Engl J Med 340: 745-750.

Ferenci P 2004. Predictors of response to therapy for chronic hepatitis C. Semin Liver Dis 24 (Suppl 2): 25-31.

Ferenci P, Fried MW, Shiffman ML, Smith CI, Marinos G, Gonçales Jr FL, Häussinger D, Diago M, Carosi G, Dhumeaux D, Craxì A, Chaneac M, Reddy KR 2005. Predicting sustained virological responses in chronic hepatitis $\mathrm{C}$ patients treated with peg-interferon alfa-2a (40 KD)/ribavirin. J Hepatol 43: 425-433.

Ferreira PRA, Santos C, Côrtes R, Reis A, Tenoren SB, Silva MH, Vilhena C, Diaz RS 2012. Association between IL28B gene polymorphisms and sustained virological response in patients coinfected with HCV and HIV in Brazil. J Antimicrob Chemother 67: 509-510.

Fischer J, Böhm S, Scholz M, Müller T, Witt H, George J, Sarrazin C, Susser S, Schott E, Suppiah V, Booth D, Stwartg J, van Bömmel F, Brodzinski A, Fülop B, Migaud P, Berg T 2012. Combined effects of different interleukin-28B gene variants on the outcome of dual combination therapy in chronic hepatitis $\mathrm{C}$ virus type $\mathrm{I}$ infection. Hepatology 55: 1700-1710.

Fried MW, Shiffman ML, Reddy KR, Smith C, Marinos G, Gonçales Jr FL, Häussinger D, Diago M, Carosi G, Dhumeaux D, Craxi A, Lin A, Hoffman J, Yu J 2002. Peg-interferon alfa-2a plus ribavirin for chronic hepatitis C virus infection. N Engl J Med 347: 975-982.

Fukuhara T, Taketomi A, Motomura T, Okano S, Ninomiya A, Abe T, Uchiyama H, Soejima Y, Shirabe K, Matsuura Y, Maehara Y 2010. Variants in IL28B in liver recipients and donors correlate with response to peg-interferon and ribavirin therapy for recurrent hepatitis C. Gastroenterology 139: 1577-1585.

Ge D, Fellay J, Thompson AJ, Simon JS, Shianna KV, Urban TJ, Heinzen EL, Qiu P, Bertelsen AH, Muir AJ, Sulkowski M, McHutchison JG, Goldstein DB 2009. Genetic variation in IL28B predicts hepatitis C treatment-induced viral clearance. Nature 461: 399-401.

Ghany MG, Strader DB, Thomas DL, Seeff LB 2009. Diagnosis, management and treatment of hepatitis C: an update. Hepatology 49: 1335-1374.

IBGE - Instituto Brasileiro de Geografia e Estatística 2000. Brasil 500 anos de povoamento. Available from: ibge.gov.br/brasil500/ index $2 . \mathrm{html}$.

Lindh M, Lagging M, Norkrans G, Hellstrand K 2010. A model explaining the correlations between IL28B-related genotypes, hepatitis C virus genotypes and viral RNA levels. Gastroenterology 139: 1794-1796. 
Lunge VR, da Rocha DB, Béria JU, Tietzmann DC, Stein AT, Simon D 2012. IL28B polymorphism associated with spontaneous clearance of hepatitis C infection in a southern Brazilian HIV type 1 population. AIDS Res Hum Retroviruses 28: 215-219.

Manns MP, McHutchison JG, Gordon SC, Rustgi VK, Shiffman M, Reindollar R, Goodman ZD, Koury K, Ling M, Albrecht JK 2001. Peginterferon alfa- $2 \mathrm{~b}$ plus ribavirin compared with interferon alfa- $2 b$ plus ribavirin for initial treatment of chronic hepatitis $\mathrm{C}$ : $\mathrm{a}$ randomised trial. Lancet 358: 958-965.

Marabita F, Aghemo A, de Nicola S, Rumi MG, Cheroni C, Scavelli R, Crimi M, Soffredini R, Abrignani S, de Francesco R, Colombo M 2011. Genetic variation in the interleukin-28B gene is not associated with fibrosis progression in patients with chronic hepatitis $\mathrm{C}$ and known date of infection. Hepatology 54: 1127-1134.

McHutchison JG, Lawitz EJ, Shiffman ML, Galler GW, McCone J, Nyberg LM, Lee WM, Ghalib RH, Schiff ER, Galati JS, Bacon BR, Davis MN, Mukhopadhyay P, Koury K, Noviello S, Pedicone LB, Brass CA, Albrecht JK, Sulkowski MS, IDEAS Study Team 2009. Peginterferon alfa-2b or alfa-2a with ribavirin for treatment of hepatitis C infection. N Engl J Med 361: 580-593.

McHutchison JG, Shad JA, Gordon SC, Morgan TR, Ling MH, Garaud JJ, Albrecht JK, Dienstag JL 2001. Predicting response to initial therapy with interferon plus ribavirin in chronic hepatitis $\mathrm{C}$ using serum HCV RNA results during therapy. $J$ Viral Hepat 8: 414-420.

Moraes Coelho HS, Villela-Nogueira CA 2010. Predictors of response to chronic hepatitis C treatment. Ann Hepatol 9 (Suppl.): S54-S60.

Poynard T, McHutchison J, Davis GL, Esteban-Mur R, Goodman $\mathrm{Z}$, Bedossa $\mathrm{P}$, Albrecht $\mathrm{J} 2000$. Impact of interferon alfa-2b and ribavirin on progression of liver fibrosis in patients with chronic hepatitis C. Hepatology 32: 1131-1137.

Rauch A, Kutalik Z, Descombes P, Cai T, Di Iulio J, Mueller T, Bochud M, Battegay M, Bernasconi E, Borovicka J, Colombo S, Cerny A, Dufour JF, Furrer H, Günthard HF, Heim M, Hirschel B, Malinverni R, Moradpour D, Müllhaupt B, Witteck A, Beckmann JS, Berg T, Bergmann S, Negro F, Telenti A, Bochud PY; Swiss Hepatitis C Cohort Study; Swiss HIV Cohort Study. Genetic variation in IL28B is associated with chronic hepatitis C and treatment failure: a genome-wide association study 2010 . Gastroenterology 138: 1338-1345.

Shebl FM, Maeder D, Shao Y, Prokunina-Olsson L, Schadt EE, O'Brien TR 2010. In the absence of HCV infection, interferon stimulated gene expression in liver is not associated with IL28B genotype. Gastroenterology 139: 1422-1424.

Silva R, Moura-Neto RS 2004. Genetic diversity and admixture data on 11 STRs (F13B, TPOX, CSF1PO, F13A01, D7S820, LPL, TH01, vWA, D13S317, FESFPS and D16S539) in a sample of Rio de Janeiro European-descendants population, Brazil. Forensic Sci Int 142: 51-53.

Suppiah V, Moldovan M, Ahlenstiel G, Berg T, Weltman M, Abate ML, Bassendine M, Spengler U, Dore GJ, Powell E, Riordan S, Sheridan D, Smedile A, Fragomeli V, Müller T, Bahlo M, Stewart GJ, Booth DR, George J 2009. IL28B is associated with response to chronic hepatitis $\mathrm{C}$ interferon-alpha and ribavirin therapy. Nat Genet 41: 1100-1104.

Tanaka Y, Nishida N, Sugiyama M, Kurosaki M, Matsuura K, Sakamoto N, Nakagawa M, Korenaga M, Hino K, Hige S, Ito Y, Mita E, Tanaka E, Mochida S, Murawaki Y, Honda M, Sakai A, Hiasa Y, Nishiguchi S, Koike A, Sakaida I, Imamura M, Ito K, Yano K, Masaki N, Sugauchi F, Izumi N, Tokunaga K, Mizokami M 2009. Genome-wide association of IL28B with response to pegylated interferon-alpha and ribavirin therapy for chronic hepatitis C. Nat Genet 41: 1105-1109.

Thompson AJ, Muir AJ, Sulkowski MS, Ge D, Fellay J, Shianna KV, Urban T, Afdhal NH, Jacobson IM, Esteban R, Poordad F, Lawitz EJ, McCone J, Shiffman ML, Galler GW, Lee WM, Reindollar R, King JW, Kwo PY, Ghalib RH, Freilich B, Nyberg LM, Zeuzem S, Poynard T, Vock DM, Pieper KS, Patel K, Tillmann HL, Noviello S, Koury K, Pedicone LD, Brass CA, Albrecht JK, Goldstein DB, McHutchison JG 2010. IL28B polymorphism improves viral kinetics and is the strongest pre-treatment predictor of SVR in HCV-1 Patients. Gastroenterology 139: 120-129.

Tillmann HL, Thompson AJ, Patel K, Wiese M, Tenckhoff H, Nischalke HD, Lokhnygina Y, Kullig U, Göbel U, Capka E, Wiegand J, Schiefke I, Güthoff W, Grüngreiff K, König I, Spengler U, McCarthy J, Shianna KV, Goldstein DB, McHutchison JG, Timm J, Nattermann J, German Anti-D Study Group 2010. A polymorphism near IL28B is associated with spontaneous clearance of acute hepatitis C virus and jaundice. Gastroenterology 139: 1586-1592.

Villela-Nogueira CA, Perez RM, de Segadas Soares JA, Coelho HS 2005. Gamma-glutamyl transferase (GGT) as an independent predictive factor of sustained virologic response in patients with hepatitis $\mathrm{C}$ treated with interferon-alpha and ribavirin. J Clin Gastroenterol 39: 728-730. 